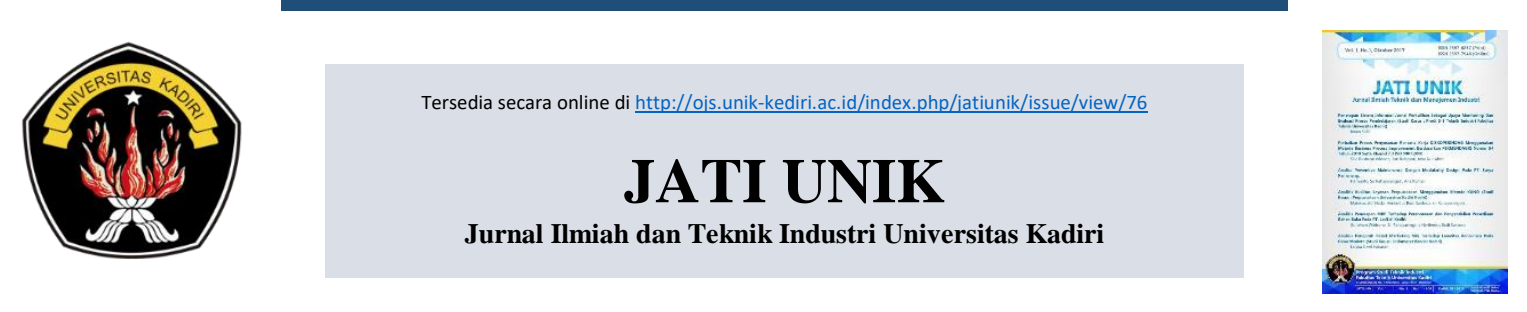

\title{
Pengukuran Produktivitas Dengan Menggunakan Metode Objective Matrix di PT.ABC
}

\author{
Muhammad Bob Anthony ${ }^{(1)}$ \\ (1) Program Studi Teknik Industri, Fakultas Teknik, Universitas Serang Raya \\ Email : tonypbmti@gmail.com ${ }^{(1)}$
}

\section{Informasi Artikel}

Riwayat Artikel :

Received : 10 - Septermber - 2019

Revised : 21 -September-2019

Accepted : 25 - Oktober - 2019

Kata kunci :

Objective Matrix

Tank Cleaning

Productivity Measurement

\begin{abstract}
A b stract
PT. $A B C$ is a chemical company that produces emulsions. Evaluation of performance development in the production department requires a measurement of productivity with the aim of knowing the level of productivity in the production section that has been achieved based on the criteria that are indicators of productivity in the form of ratios, identifying the causes of the decline in productivity and making improvement plans in an effort to continuously increase productivity. The method used in measuring productivity in this study is the Objective Matrix method so the steps in this study refer to the need for matrix formation. Based on the measurement of the productivity value in the production section before making improvements with the Objective Matrix method for the 6 months period July 2017 to December 2017 the lowest productivity value was obtained in December 2017. The factor that caused this lowest productivity value was the very long reactor washing for 24 hours. Washing the reactor is very long because the washing method is still done manually. The productivity value increased after there was an improvement by shortening the reactor cleaning time by using the 300 bar pressurized water jet cleaner method, namely in January 2019 to 738 or $560.76 \%$ compared to the previous period and an increase of $146.0 \%$ compared to the standard productivity value.
\end{abstract}

Untuk melakukan sitasi pada penelitian ini dengan format :

F. A. Pratama and H. Henny, "Analisis Produktivitas Objective Matrix (Omax) Ditinjau Dari Keselamatan Dan Kesehatan Kerja Dilantai Produksi Di Cv. Grand Manufacturing Indonesia," Ina. J. Ind. Qual. Eng., vol. 6, no. 2, pp. 1-8, 2018, doi: 10.34010/iqe.v6i2.987.

\begin{abstract}
A b s trak
PT. ABC merupakan salah satu perusahaan kimia yang memproduksi emulsi. Evaluasi perkembangan kinerja di bagian produksi memerlukan suatu pengukuran produktivitas dengan tujuan mengetahui tingkat produktivitas di bagian produksi yang telah dicapai berdasarkan kriteria-kriteria yang menjadi indikator produktivitas dalam bentuk rasio, mengidentifikasi penyebab terjadinya penurunan produktivitas dan melakukan perencanaan perbaikan sebagai upaya peningkatan produktivitas secara berkesinambungan. Metode yang digunakan dalam pengukuran produktivitas dalam penelitian ini adalah metode Objective Matrix
\end{abstract}


sehingga langkah-langkah pada penelitian ini mengacu pada kebutuhan pembentukan matrik. Berdasarkan pengukuran nilai produktivitas di bagian produksi sebelum dilakukan perbaikan dengan metode Objective Matrix selama 6 bulan periode Juli 2017 sampai Desember 2017 diperoleh nilai produktivitas terendah di bulan Desember 2017. Faktor yang menyebabkan nilai produktivitas terendah ini adalah pencucian reaktor yang sangat lama yaitu selama 24 jam. Pencucian reaktor ini sangat lama dikarenakan metode pencucian masih dilakukan secara manual. Nilai produktivitas mengalami peningkatan setelah ada perbaikan dengan mempersingkat waktu pencucian reaktor dengan menggunakan metode water jet cleaner bertekanan 300 bar yaitu pada Januari 2019 menjadi 738 atau 560.76\% dibandingkan periode sebelumnya dan mengalami peningkatan $146.0 \%$ dibandingkan nilai produktivitas standar.

\section{Pendahuluan}

PT. ABC merupakan salah satu industri manufaktur bahan kimia polimer emulsion yang berfungsi sebagai bahan perekat (binder) digunakan pada kayu, tekstil, cat, kertas, beton dan lain lain. Jenis polimer emulsion yang diproduksi adalah: Polivinyl Acetate (PVAc), Styrene Acrylic, Vinyl Acrylic, Vinyl Veova, dan All Acrylic. Untuk meningkatkan output produksi secara efektif dan effisien, maka perusahaan melakukan pengukuran produktivitas. Pengukuran produktivitas PT. ABC selama ini belum optimal karena perusahaan hanya membandingkan output produksi terhadap jam kerja saja. Penambahan jam kerja berarti ada penambahan biaya sedangkan sumber daya lain yang digunakan seperti penggunaan listrik, tenaga kerja dan kapasitas mesin tidak dimasukan kedalam perhitungan produktivitas. Untuk meningkatkan produktivitas, PT. ABC harus melakukan pengukuran produktivitas secara optimal yang akan memberikan evaluasi produktivitas yaitu dengan memasukan sumber daya, jam kerja, penggunaan listrik, tenaga kerja dan kapasitas mesin terpasang. Penelitian ini menggunakan metode Objective Matrix untuk mengukur produktivitas di PT. ABC. Metode Objective Matrix digunakan karena relatif sederhana, mudah dipahami, mudah dilaksanakan, tidak memerlukan keahlian khusus dan data lebih mudah didapatkan [1],[2],[3],[4].

\section{TINJAUAN PUSTAKA}

\subsection{Objective Matrix (OMAX)}

Objective Matrix (OMAX) adalah suatu sistem pengukuran produktivitas parsial yang dikembangkan untuk memantau produktivitas ditiap bagiannya dengan kriteria produktivitasnya yang sesuai dengan keberadaan bagian tersebut (objective). Metode ini dikembangkan oleh seorang Professor produktivitas dari Departement of Industrial Engineering at Oregon State University yaitu James L.Riggs, PE. OMAX diperkenalkan pada tahun 80-an di Amerika Serikat. Adapun 3 fungsi atau kegunaan dari OMAX itu sendiri adalah :

a. Sebagai sarana pengukuran produktivitas

b. Sebagai alat dalam memecahkan masalah produktivitas 
c. Alat pemantau pertumbuhan produktivitas

\subsection{Konsep Produktivitas}

Istilah produktivitas pertama kali muncul tahun 1776 dalam naskah yang disusun oleh Qusney dari Perancis. Namun filosofi dan keberadaan produktivitas sudah ada sejak awal peradaban manusia di muka bumi ini. Makna dari produktivitas adalah suatu upaya atau keinginan menusia untuk selalu meningkatkan kualitas hidupnya dengan menggunakan sumber daya sekecil mungkin. Penerapan aliran produksi yang searah dan lancar maupun penanganan beberapa proses sekaligus sangat berguna bagi penyempurnaan produktivitas kerja, kualitas, waktu penyerahan produksi, tingkat persediaan, dan pemanfaatan ruang [5] Produktivitas tidak sama dengan produksi tetapi produksi, performasi kualitas, hasil-hasil merupakan komponen dari usaha produktivitas. Dengan demikian, produktivitas merupakan suatu kombinasi dari efektifitas dengan efisien [6]

\section{Metode Penelitian}

Objek penelitian ini adalah bagian produksi emulsi salah satu perusahaan berskala internasional yang bergerak dibidang industri manufaktur kimia. Data yang di ambil adalah data laporan harian perusahaan bagian produksi selama 6 bulan yaitu Januari 2017 hingga Desember 2017.

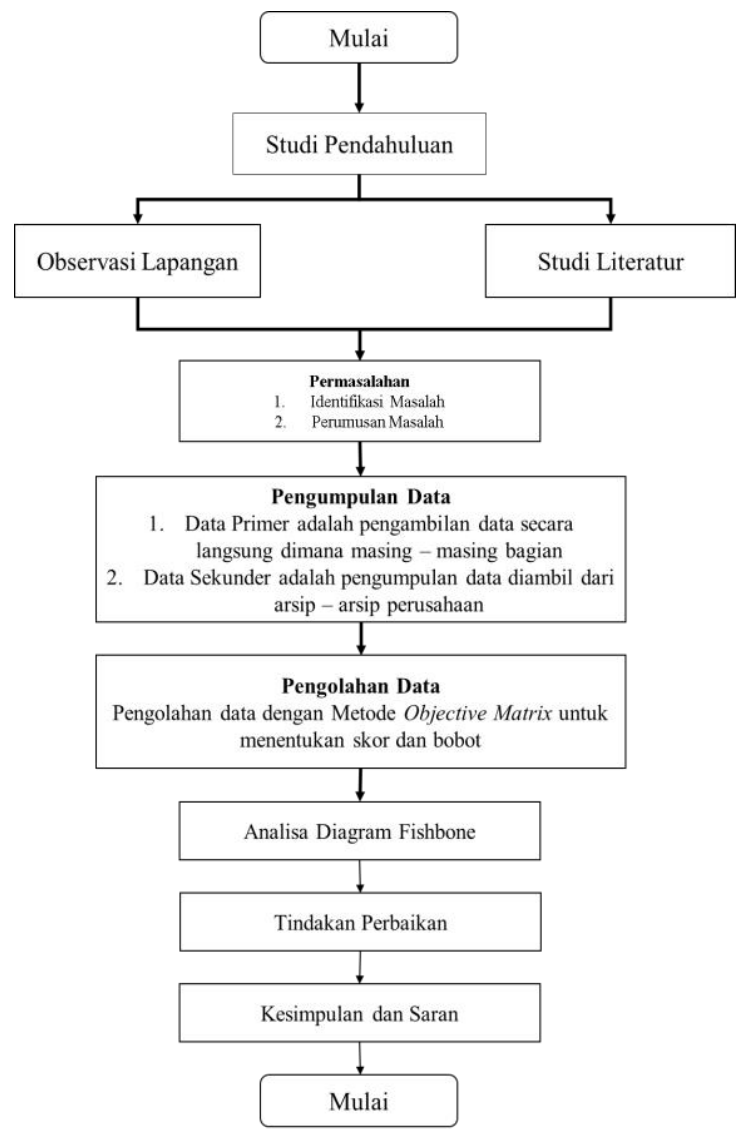

Gambar 1 Diagram Alir Penelitian 
Menurut Rigg dan Glenn dalam Fihtri dan Firdaus [7], Objective Matrix merupakan salah metode pengukuran kinerja multi kriteria dengan indikator kinerja yang disesuaikan pada ukuran organisasi [8], [9].

Menurut Balkan dalam Pakpahan, Suhardini, dan Ehsy [10], Objective Matrix (OMAX) adalah suatu sistem pengukuran produktivitas parsial yang dikembangkan untuk memantau produktivitas di setiap bagian perusahaan dengan kriteria produktivitas yang sesuai dengan beberapa kriteria produktivitas yang sesuai dengan kondisi perusahaan dengan cara melakukan pembobotan untuk mendapatkan indeks produktivitas total [11],[12],[13], [14]. Penggunaan metode ini dengan tahapan sebagai berikut :

\subsection{Penentuan kriteria produktivitas}

Dalam penggunaan kriteria produktivitas pada pengukuran di lini produksi menggunakan rasio sebagai berikut [15], [16]:

a. Rasio 1 adalah perbandingan yang digunakan pada produksi emulsion sebagai output dengan jam kerja sebagai input.

b. Rasio 2 adalah perbandingan antara produksi emulsion sebagai output dan pemakaian energi listrik sebagai input.

c. Rasio 3 adalah perbandingan antara jumlah produksi emulsion dengan jumlah tenaga kerja.

d. Rasio 3 adalah perbandingan antara jumlah produksi emulsion dengan kapasitas produksi.

\subsection{Perhitungan Rasio}

Data kriteria produktivitas yang telah terkumpul selanjutnya dikonversikan menjadi nilai rasio sesuai dengan kriteria yang telah ditetapkan sebelumnya [1], [15].

\subsection{Penentuan Nilai Sasaran}

Menurut Mahmudi [17], dalam menentukan nilai sasaran dari setiap kriteria produktivitas, nilai sasaran ini merupakan nilai tertinggi dari setiap rasio dan menunjukan perkiraan performansi terbaik yang dapat dicapai selama rentang waktu yang akan datang dengan kondisi dan ketersediaan sumber daya yang sama pada saat proses pengukuran produktivitas dimulai. Dalam matrik sasaran, nilai ini akan ditempatkan pada level 10 [9].

\subsection{Bentuk Objective Matrix}

Hal yang penting dalam pembentukan Objective Matrix adalah penentuan skala yang mampu menggambarkan level performansi dari setiap unit kerja yang menjadi indikator produktivitas. Pada model Objective Matrix, level yang digunakan sebagai titik acuan terdiri dari 3 level, yaitu Level 0, Level 3 dan Level 10 [18], [19], [20].

\subsection{Pengukuran Produktivitas di Bagian Produksi}

Pengukuran produktivitas standar lini produksi merupakan performansi lini produksi berdasarkan nilai tahap awal yang ditetapkan pada periode dasar pengukuran didalam lingkungan kerja [21], [22].

\subsection{Pengukuran Produktivitas Lini Produksi Periode Pengukuran}

Didalam menentukan nilai produktivitas setiap rasio dengan mengalikan skor yang didapat dengan bobot yang diberikan. Penggunaan formula untuk mengkonversi bobot sebagai berikut [17], [23], [24]: 


$$
\text { Nilai bobot yang dikonversikan }=\frac{\text { Nilai bobot }}{\text { Total nilai bobot }} \times 100 \%
$$

Setelah dilakukan penentuan nilai bobot produktivitas keseluruhan pada periode dengan cara menjumlahkan nilai produktivitas tiap rasio, dilakukan penentuan nilai indeks perubahan terhadap produktivitas pada periode sebelumnya dengan formula sebagai berikut [16] :

$$
I P=\frac{\text { Current }_{i}-\text { Previous }_{i}}{\text { Previous }_{i}} \times 100 \%
$$

Keterangan :

IP $\quad=$ Indeks produktivitas

Current $_{\mathrm{i}}=$ Nilai kriteria saar pengukuran periode tertentu

Previous $_{\mathrm{i}}=$ Nilai kriteria periode sebelumnya

3.7. Perhitungan Nilai Indeks Perubahan terhadap Produktivitas Standar

Untuk mengukur nilai indeks perubahan terhadap produktivitas standar menggunakan formula sebagai berikut [9], [25], [24] :

$$
I P=\frac{\text { Current }- \text { Standart }}{\text { Standart }} \times 100 \%
$$

Keterangan :

IP $\quad=$ Indeks produktivitas

Current $\quad=$ Nilai kriteria saar pengukuran

Standart = Nilai kriteria standar periode tertentu

\section{Hasil dan Pembahasan}

Tabel 1 Rasio 1 Output Jam Kerja

\begin{tabular}{|c|c|c|c|}
\hline Bulan & $\begin{array}{c}\text { Output Produksi } \\
(\mathrm{Kg})\end{array}$ & $\begin{array}{c}\text { Jam } \\
\text { Kerja }\end{array}$ & Rasio 1 \\
\hline Juli & 682,873 & 6,114 & 111,69 \\
\hline Agustus & 697,879 & 4,631 & 150,68 \\
\hline September & 665,680 & 3850,5 & 172,88 \\
\hline Oktober & 741,109 & 4944 & 149,90 \\
\hline November & 763,665 & 5756,5 & 132,66 \\
\hline Desember & 581,860 & 4630 & 125,67 \\
\hline \multicolumn{3}{|c|}{ Rasio Minimum } & 111,69 \\
\hline \multicolumn{3}{|c|}{ Rasio Rata-rata } & 140,68 \\
\hline
\end{tabular}

(Sumber : Olah Data) 
Tabel 2 Rasio 2 Output Pemakaian Listrik

\begin{tabular}{|c|c|c|c|}
\hline Bulan & $\begin{array}{c}\text { Output Produksi } \\
(\mathrm{Kg})\end{array}$ & $\begin{array}{c}\text { Listrik } \\
(\mathrm{KWh})\end{array}$ & Rasio 2 \\
\hline Juli & 682,873 & 34,42 & 19,84 \\
\hline Agustus & 697,879 & 33,13 & 21,06 \\
\hline September & 665,680 & 21,58 & 30,85 \\
\hline Oktober & 741,109 & 30,28 & 24,48 \\
\hline November & 763,665 & 30,95 & 24,67 \\
\hline Desember & 581,860 & 31,22 & 18,64 \\
\hline \multicolumn{3}{|c|}{ Rasio Minimum } & 18,64 \\
\hline \multicolumn{3}{|c|}{ Rasio Rata-rata } & 23,26 \\
\hline Rasio Maksimum & 30,85 \\
\hline
\end{tabular}

(Sumber : Olah Data)

Tabel 3 Rasio 3Output Jumlah Tenaga Kerja

\begin{tabular}{|c|c|c|c|}
\hline Bulan & $\begin{array}{c}\text { Output Produksi } \\
(\mathrm{Kg})\end{array}$ & $\begin{array}{c}\text { Jumlah Tenaga } \\
\text { Kerja }\end{array}$ & Rasio 3 \\
\hline Juli & 682,873 & 32 & 21339,78 \\
\hline Agustus & 697,879 & 25 & 27911,56 \\
\hline September & 665,680 & 26 & 25603,08 \\
\hline Oktober & 741,109 & 26 & 2850419 \\
\hline November & 763,665 & 32 & 2386453 \\
\hline Desember & 581,860 & 31 & 1876968 \\
\hline \multicolumn{3}{|c|}{ Rasio Minimum } & 18769,68 \\
\hline \multicolumn{3}{|c|}{ Rasio Rata-rata } & 24332,14 \\
\hline \multicolumn{3}{|c|}{ Rasio Maksimum } \\
\hline
\end{tabular}

(Sumber : Olah Data)

Tabel 4 Output Kapasitas Mesin

\begin{tabular}{|c|c|c|c|}
\hline Bulan & Output Produksi (Kg) & $\begin{array}{c}\text { Jumlah Tenaga } \\
\text { Kerja }\end{array}$ & Rasio 4 \\
\hline Juli & 682,873 & 927000 & 70,4 \\
\hline Agustus & 697,879 & 927000 & 71,94 \\
\hline September & 665,680 & 927000 & 68,63 \\
\hline Oktober & 741,109 & 927000 & 76,40 \\
\hline November & 763,665 & 927000 & 78,73 \\
\hline Desember & 581,860 & 927000 & 59,99 \\
\hline \multicolumn{3}{|c|}{ Rasio Minimum } & 59,99 \\
\hline \multicolumn{3}{|c|}{ Rasio Rata-rata } & 71,01 \\
\hline \multicolumn{3}{|c}{ Rasio Maksimum } \\
\hline
\end{tabular}

(Sumber : Olah Data) 


\subsection{Penentuan Nilai Sasaran}

Tabel 5 Nilai Tahap Awal Setiap Rasio Rata- Rata

\begin{tabular}{|c|c|c|c|}
\hline Rasio 1 & Rasio 2 & Rasio 3 & Rasio 4 \\
\hline 140,58 & 23,26 & 24332,14 & 71,01 \\
\hline
\end{tabular}

(Sumber : Olah Data)

Tabel 6 Nilai Tahap Awal Setiap Rasio Minimum

\begin{tabular}{|c|c|c|c|}
\hline Rasio 1 & Rasio 2 & Rasio 3 & Rasio 4 \\
\hline 111,69 & 18,64 & 18769,68 & 59,99 \\
\hline
\end{tabular}

(Sumber : Olah Data)

Tabel 7 Nilai Sasaran Masing - Masing Rasio Maksimal

\begin{tabular}{|c|c|c|c|}
\hline Rasio 1 & Rasio 2 & Rasio 3 & Rasio 4 \\
\hline 111,69 & 18,64 & 18769,68 & 59,99 \\
\hline
\end{tabular}

(Sumber : Olah Data)

Table 8 Nilai Bobot

\begin{tabular}{|c|c|}
\hline Rasio & Nilai \\
\hline 1 & 8 \\
\hline 2 & 10 \\
\hline 3 & 10 \\
\hline 4 & 9 \\
\hline Jumlah & 37 \\
\hline
\end{tabular}

(Sumber : Olah Data)

Table 9 Nilai Bobot Masing - Masing Ratio

\begin{tabular}{|c|c|c|c|}
\hline Rasio 1 & Rasio 2 & Rasio 3 & Rasio 4 \\
\hline 22 & 27 & 27 & 24 \\
\hline
\end{tabular}

(Sumber : Olah Data)

\subsection{Bentuk Objective Matrix}

Table 10 Bentuk Awal Objective Matrix

\begin{tabular}{|l|l|l|l|l|l|}
\hline $\begin{array}{l}\text { Rasio } \\
1\end{array}$ & $\begin{array}{l}\text { Rasio } \\
2\end{array}$ & Rasio 3 & Rasio 4 & \multicolumn{2}{|l|}{$\begin{array}{l}\text { Productivity/ } \\
\text { Criteria }\end{array}$} \\
\hline & & & & \multicolumn{2}{|c|}{ Performance } \\
\hline 172,88 & 30,85 & 28504,19 & 78,73 & 10 & \multirow{2}{*}{} \\
\hline & & & & 9 \\
\hline & & & & 8 & \multirow{2}{*}{ Score } \\
\hline & & & & 7 & \\
\hline & & & & 6 & 5 \\
\hline & & & & 4 & \multicolumn{2}{|c|}{} \\
\hline & & & & 4 & \multicolumn{2}{|l}{} \\
\hline
\end{tabular}




\begin{tabular}{|c|c|c|c|c|}
\hline 140,58 & 23,26 & 24332,14 & 71,01 & 3 \\
\hline & & & & 2 \\
\hline & & & & 1 \\
\hline \multirow[t]{3}{*}{111,69} & 18,64 & 18769,68 & 59,99 & 0 \\
\hline & & & & Skor \\
\hline & & & & Bobot \\
\hline 22 & 27 & 27 & 24 & Nilai \\
\hline & rfor & e Indic & & \\
\hline
\end{tabular}

Setelah diketahui bentuk awal dari Objective Matrix dilakukan perhitungan dengan hasil nilai produktivitas standar pada Objective Matrix sebagai berikut [26], [27] :

Table 11 Nilai Produktivitas Standar

\begin{tabular}{|c|c|c|c|c|c|}
\hline $\begin{array}{l}\text { Rasio } \\
1\end{array}$ & $\begin{array}{l}\text { Rasio } \\
2\end{array}$ & Rasio 3 & Rasio 4 & Productiv & Criteria \\
\hline 140,58 & 23,26 & 24332,14 & 71,01 & \multicolumn{2}{|c|}{ Performance } \\
\hline 172,88 & 30,85 & 28504,19 & 78,73 & 10 & \multirow{11}{*}{ Score } \\
\hline 168,27 & 29,76 & 27908,18 & 77,63 & 9 & \\
\hline 163,65 & 28,68 & 27312,18 & 76,52 & 8 & \\
\hline 159,04 & 27,59 & 26716,17 & 75,42 & 7 & \\
\hline 154,42 & 26,51 & 26120,16 & 74,32 & 6 & \\
\hline 149,81 & 25,42 & 25524,15 & 73,22 & 5 & \\
\hline 145,19 & 24,34 & 24928,14 & 72,12 & 4 & \\
\hline 140,58 & 23,26 & 24332,14 & 71,01 & 3 & \\
\hline 130,95 & 21,72 & 22477,98 & 67,34 & 2 & \\
\hline 121,32 & 20,18 & 20623,83 & 63,66 & 1 & \\
\hline 111,69 & 18,64 & 18769,68 & 59,99 & 0 & \\
\hline 3 & 3 & 3 & 3 & Skor & \\
\hline 22 & 27 & 27 & 24 & Bobot & \\
\hline 66 & 81 & 81 & 72 & Nilai & \\
\hline \multirow{2}{*}{\multicolumn{3}{|c|}{ Performance Indicator }} & Current & Previous & Index \\
\hline & & & 300,0 & & \\
\hline
\end{tabular}

(Sumber : Olah Data)

\subsection{Perhitungan Produktivitas Bagian Produksi}

Table 12 Nilai Produktivitas Bulan Julli 2017

\begin{tabular}{|l|l|l|l|l|}
\hline $\begin{array}{l}\text { Rasio } \\
1\end{array}$ & $\begin{array}{l}\text { Rasio } \\
2\end{array}$ & Rasio 3 & Rasio 4 & Productivity/ Criteria \\
\hline
\end{tabular}




\begin{tabular}{|c|c|c|c|c|c|}
\hline 111,69 & 18,64 & 18769,68 & 59,99 & \multicolumn{2}{|c|}{ Performance } \\
\hline 172,88 & 30,85 & 28504,19 & 78,73 & 10 & \multirow{11}{*}{ Score } \\
\hline 168,27 & 29,76 & 27908,18 & 77,63 & 9 & \\
\hline 163,65 & 28,68 & 27312,18 & 76,52 & 8 & \\
\hline 159,04 & 27,59 & 26716,17 & 75,42 & 7 & \\
\hline 154,42 & 26,51 & 26120,16 & 74,32 & 6 & \\
\hline 149,81 & 25,42 & 25524,15 & 73,22 & 5 & \\
\hline 145,19 & 24,34 & 24928,14 & 72,12 & 4 & \\
\hline 140,58 & 23,26 & 24332,14 & 71,01 & 3 & \\
\hline 130,95 & 21,72 & 22477,98 & 67,34 & 2 & \\
\hline 121,32 & 20,18 & 20623,83 & 63,66 & 1 & \\
\hline 111,69 & 18,64 & 18769,68 & 59,99 & 0 & \\
\hline 0 & 1 & 1 & 2 & Skor & \\
\hline 22 & 27 & 27 & 24 & Bobot & \\
\hline 0 & 27 & 27 & 48 & Nilai & \\
\hline \multirow{2}{*}{\multicolumn{3}{|c|}{ Performance Indicator }} & Current & Previous & Index \\
\hline & & & 102,0 & & \\
\hline
\end{tabular}

(Sumber : Olah Data)

\subsection{Perhitungan Produktivitas Lini Produksi Periode Pengukuran}

Table 13 Nilai Produktivitas Bulan Agustus 2017

\begin{tabular}{|c|c|c|c|c|c|}
\hline Rasio & Rasio & Rasio 3 & Rasio 4 & \multicolumn{2}{|c|}{ Productivity/Criteria } \\
\hline 150,68 & 21,06 & 27911,56 & 71,95 & \multicolumn{2}{|c|}{ Performance } \\
\hline 172,88 & 30,85 & 28504,19 & 78,73 & 10 & \multirow{11}{*}{ Score } \\
\hline 168,27 & 29,76 & 27908,18 & 77,63 & 9 & \\
\hline 163,65 & 28,68 & 27908,18 & 76,52 & 8 & \\
\hline 159,04 & 27,59 & 26716,17 & 75,42 & 7 & \\
\hline 154,42 & 26,51 & 26120,16 & 74,32 & 6 & \\
\hline 149,81 & 25,42 & 25524,15 & 73,22 & 5 & \\
\hline 145,19 & 24,34 & 24928,14 & 72,12 & 4 & \\
\hline 140,58 & 23,26 & 24332,14 & 71,12 & 3 & \\
\hline 130,95 & 21,72 & 22477,98 & 67,34 & 2 & \\
\hline 121,32 & 20,18 & 20623,83 & 63,66 & 1 & \\
\hline 111,69 & 18,64 & 18769,68 & 59,99 & 0 & \\
\hline 5 & 1 & 9 & 3 & Skor & \\
\hline 22 & 27 & 27 & 24 & Bobot & \\
\hline 110 & 27 & 243 & 72 & Nilai & \\
\hline \multirow{2}{*}{\multicolumn{3}{|c|}{ Performance Indicator }} & Current & Previous & Index \\
\hline & & & 452,0 & 102 & 343,1 \\
\hline
\end{tabular}

(Sumber : Olah Data) 
Table 14 Nilai Produktivitas Bulan September 2017

\begin{tabular}{|c|c|c|c|c|c|}
\hline $\begin{array}{l}\text { Rasio } \\
1\end{array}$ & $\begin{array}{l}\text { Rasio } \\
2\end{array}$ & Rasio 3 & Rasio 4 & \multicolumn{2}{|c|}{ Productivity/ Criteria } \\
\hline 172,88 & 30,85 & 25603,08 & 68,63 & \multicolumn{2}{|c|}{ Performance } \\
\hline 172,88 & 30,85 & 28504,19 & 78,73 & 10 & \multirow{11}{*}{ Score } \\
\hline 168,27 & 29,76 & 27908,18 & 77,63 & 9 & \\
\hline 163,65 & 28,68 & 27312,18 & 76,52 & 8 & \\
\hline 159,04 & 27,59 & 26716,17 & 75,42 & 7 & \\
\hline 154,42 & 26,51 & 26120,16 & 74,32 & 6 & \\
\hline 149,81 & 25,42 & 25524,15 & 73,22 & 5 & \\
\hline 145,19 & 24,34 & 24928,14 & 72,12 & 4 & \\
\hline 140,58 & 23,26 & 24332,14 & 71,01 & 3 & \\
\hline 130,95 & 21,72 & 22477,98 & 67,34 & 2 & \\
\hline 121,32 & 20,18 & 20623,83 & 63,66 & 1 & \\
\hline 111,69 & 18,64 & 18769,68 & 59,99 & 0 & \\
\hline 10 & 10 & 6 & 2 & Skor & \\
\hline 22 & 27 & 27 & 24 & Bobot & \\
\hline 220.0 & 270.0 & 162.0 & 48.0 & Nilai & \\
\hline \multirow{2}{*}{\multicolumn{3}{|c|}{ Performance Indicator }} & Current & Previous & Index \\
\hline & & & 700.0 & 452 & 54.9 \\
\hline
\end{tabular}

(Sumber : Olah Data)

Table 15 Nilai Produktivitas Bulan Oktober 2017

\begin{tabular}{|l|l|l|l|l|l|}
\hline $\begin{array}{l}\text { Rasio } \\
1\end{array}$ & $\begin{array}{l}\text { Rasio } \\
2\end{array}$ & Rasio 3 & Rasio 4 & \multicolumn{2}{|l|}{ Productivity/ Criteria } \\
\hline 149.90 & 24.48 & 28504,19 & 76,40 & \multicolumn{2}{|c|}{ Performance } \\
\hline 172,88 & 30,85 & 28504,19 & 78,73 & 10 & \multirow{2}{*}{} \\
\hline 168,27 & 29,76 & 27908,18 & 77,63 & 9 & \multirow{2}{*}{ Score } \\
\hline 163,65 & 28,68 & 27312,18 & 76,52 & 8 & \multirow{2}{*}{} \\
\hline 159,04 & 27,59 & 26716,17 & 75,42 & 7 & \\
\hline 154,42 & 26,51 & 26524,15 & 74,32 & 6 & \\
\hline 149,81 & 25,42 & 25524,15 & 73,22 & 5 & \\
\hline 145,19 & 24.34 & 24928,14 & 72,12 & 4 & \\
\hline 140,58 & 23,26 & 24928,14 & 71,01 & 3 & \\
\hline 130,95 & 21,72 & 22477,98 & 67,34 & 2 & \\
\hline 121,32 & 20,18 & 20623,83 & 63,66 & 1 & \\
\hline 111,69 & 18,64 & 18769,68 & 59,99 & 0 & \multicolumn{2}{|c|}{} \\
\hline 5 & 4 & 10 & 7 & Skor & \\
\hline 22 & 27 & 27 & 24 & Bobot & \\
\hline 110 & 108 & 270 & 168 & Nilai & \\
\hline
\end{tabular}




\begin{tabular}{|l|c|c|c|}
\hline \multirow{3}{*}{ Performance Indicator } & Current & Previous & Index \\
\cline { 2 - 4 } & 656 & 700 & -6.3 \\
\hline
\end{tabular}

(Sumber : Olah Data)

Table 16 Nilai Produktivitas Bulan November 2017

\begin{tabular}{|c|c|c|c|c|c|}
\hline $\begin{array}{l}\text { Rasio } \\
1\end{array}$ & $\begin{array}{l}\text { Rasio } \\
2\end{array}$ & Rasio 3 & Rasio 4 & Productiv & Criteria \\
\hline 132,66 & 24,67 & 23864,53 & 77,73 & \multicolumn{2}{|c|}{ Performance } \\
\hline 172,88 & 30,85 & 28504,19 & 78,73 & 10 & \multirow{11}{*}{ Score } \\
\hline 168,27 & 29,76 & 27908,18 & 77,63 & 9 & \\
\hline 163,65 & 28,68 & 27312,18 & 76,52 & 8 & \\
\hline 159,04 & 27,59 & 26716,17 & 75,42 & 7 & \\
\hline 154,42 & 26,51 & 26120,16 & 74,32 & 6 & \\
\hline 149,81 & 25,42 & 25524,15 & 73,22 & 5 & \\
\hline 145,19 & 24,34 & 24928,14 & 72,12 & 4 & \\
\hline 140,58 & 23,26 & 24332,14 & 71,01 & 3 & \\
\hline 130,95 & 21,72 & 22477,98 & 67,34 & 2 & \\
\hline 121,69 & 20,18 & 20623,83 & 63,66 & 1 & \\
\hline 111,69 & 18,64 & 18769,68 & 59,99 & 0 & \\
\hline 2 & 4 & 2 & 10 & Skor & \\
\hline 22 & 27 & 27 & 24 & Bobot & \\
\hline 44 & 108 & 54 & 240 & Nilai & \\
\hline \multirow{2}{*}{\multicolumn{3}{|c|}{ Performance Indicator }} & Current & Previous & Index \\
\hline & & & 426 & 656 & $-35,1$ \\
\hline
\end{tabular}

(Sumber : Olah Data)

Table 17 Nilai Produktivitas Bulan Desember 2017

\begin{tabular}{|c|c|c|c|c|c|}
\hline Rasio & Rasio & Rasio 3 & Rasio 4 & \multicolumn{2}{|c|}{ Productivity/Criteria } \\
\hline 125,67 & 18,64 & 18769,68 & 59,99 & \multicolumn{2}{|c|}{ Performance } \\
\hline 172,88 & 30,85 & 28504,19 & 78,73 & 10 & \multirow{11}{*}{ Score } \\
\hline 168,27 & 29,76 & 27908,18 & 77,63 & 9 & \\
\hline 163,65 & 28,68 & 27312,18 & 76,52 & 8 & \\
\hline 159,04 & 27,59 & 26716,17 & 75,42 & 7 & \\
\hline 154,42 & 26,51 & 26120,16 & 74,32 & 6 & \\
\hline 149,81 & 25,42 & 25524,15 & 73,22 & 5 & \\
\hline 145,19 & 24,34 & 24928,14 & 72,12 & 4 & \\
\hline 140,58 & 23,26 & 24332,14 & 71,01 & 3 & \\
\hline 130,95 & 21,72 & 22477,98 & 67,34 & 2 & \\
\hline 121,32 & 20,18 & 20623,83 & 63,66 & 1 & \\
\hline 111,69 & 18,64 & 18769,68 & 59,99 & 0 & \\
\hline 1 & 0 & 0 & 0 & Skor & \\
\hline
\end{tabular}




\begin{tabular}{|l|c|c|c|c|c|}
\hline 22 & 27 & 27 & 24 & Bobot & \\
\hline 22 & 0 & 0 & 0 & Nilai & \\
\hline \multicolumn{2}{|l|}{ Performance Indicator } & Current & Previous & Index \\
\cline { 3 - 5 } & & 22 & 426 & $-94,8$ \\
\hline
\end{tabular}

(Sumber : Olah Data)

\subsection{Pengukuran Nilai Indeks Perubahan Produktivitas Terhadap Produktivitas Standar}

Table 18 Nilai Indeks Perubahan Produktivitas terhadap Produktivitas Standar

\begin{tabular}{|l|c|c|}
\hline Bulan & $\begin{array}{c}\text { Overall } \\
\text { Productivity }\end{array}$ & $\begin{array}{c}\text { Indeks Perubahan Produktivitas } \\
(\%)\end{array}$ \\
\hline Juli & 102 & $-66,0$ \\
\hline Agustus & 452 & 50,7 \\
\hline September & 700 & 133,3 \\
\hline Oktober & 656 & 118,7 \\
\hline November & 426 & 42,0 \\
\hline Desember & 22 & $-92,7$ \\
\hline
\end{tabular}

Table 19 Nilai Indeks Perubahan Produktivitas terhadap Sebelumnya

\begin{tabular}{|l|c|c|c|}
\hline Bulan & $\begin{array}{c}\text { Nilai } \\
\text { Produktivitas } \\
\text { Total }\end{array}$ & $\begin{array}{c}\text { Indeks Perubahan } \\
\text { Terhadap } \\
\text { Produktivitas Standar } \\
(\%)\end{array}$ & $\begin{array}{c}\text { Indeks Perubahan } \\
\text { Terhadap } \\
\text { Produktivitas } \\
\text { Sebelumnya (\%) }\end{array}$ \\
\hline Juli & 102 & $-66,0$ & 0 \\
\hline Agustus & 452 & 50,7 & 343,1 \\
\hline September & 700 & 133,3 & 54,9 \\
\hline Oktober & 656 & 118,7 & $-6,3$ \\
\hline November & 426 & 42,0 & $-35,1$ \\
\hline Desember & 22 & $-92,7$ & $-94,8$ \\
\hline
\end{tabular}

(Sumber : Olah Data)

Table 20 Nilai Indeks Perubahan Skor Aktual Rasio 1 sampai Rasio 4

\begin{tabular}{|c|c|c|c|c|}
\hline Bulan & \multicolumn{4}{|c|}{ Skor Aktual } \\
\hline Juli & Rasio 1 & Rasio 2 & Rasio 3 & Rasio 3 \\
\hline Agustus & 0 & 1 & 1 & 2 \\
\hline September & 5 & 1 & 9 & 3 \\
\hline Oktober & 10 & 10 & 6 & 3 \\
\hline November & 5 & 4 & 10 & 7 \\
\hline Desember & 1 & 0 & 0 & 0 \\
\hline
\end{tabular}

(Sumber : Olah Data) 
Rasio 4 merupakan perbandingan antara produksi emulsion dengan jumlah kapasitas mesin terpasang. Semakin tinggi jumlah produksi menunjukan tingkat penggunaan mesin perusahaan semakin baik [28], [2], [29]. Pada Tabel 17 menunjukan bahwa skor untuk rasio 4 masih pada nilai dibawah dari skor rata-rata, hal ini menunjukan penggunaan mesin perusahaan tidak sesuai kapasitas terpasang. Adapun penyebab-penyebab penurunan produktivitas menggunakan diagram fishbone [30],[31],[32] pada rasio 4 bisa dilihat pada gambar berikut :

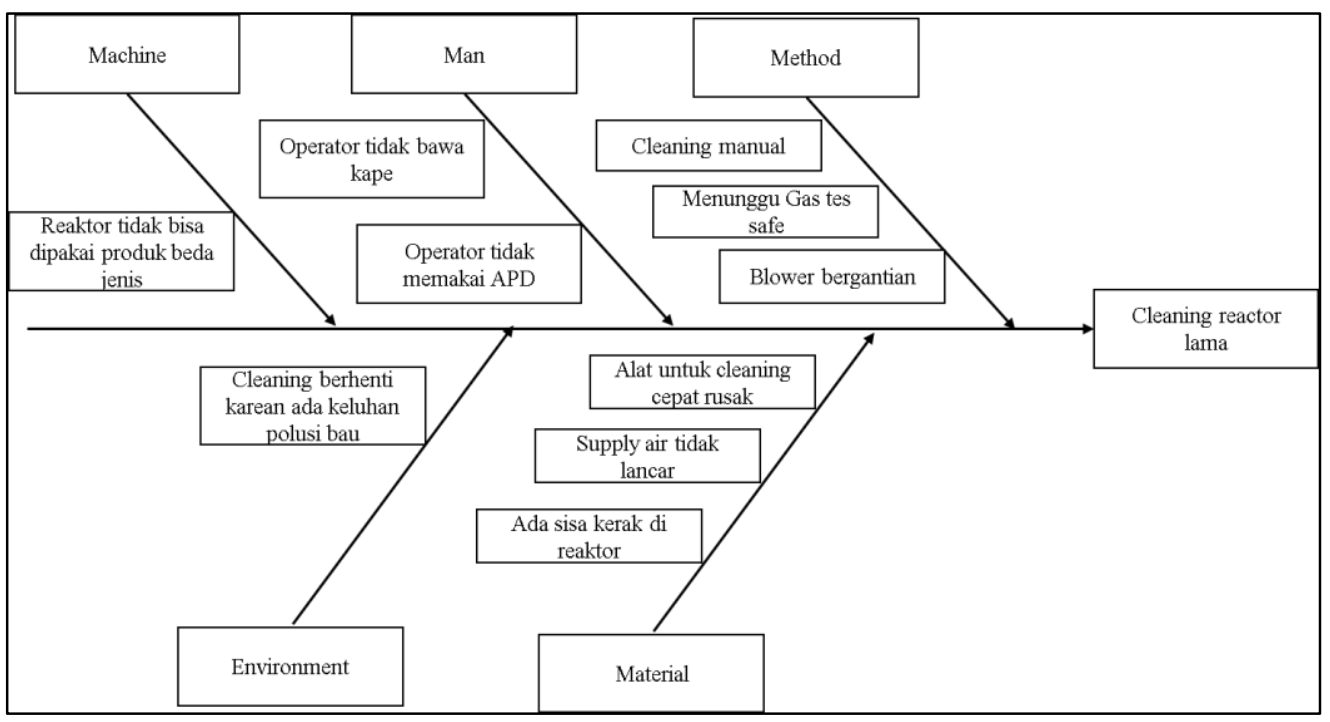

Gambar 2 Diagram Fishbone Penyebab Penurunan Produktivitas

Dari diagram fishbone didapatkan bahwa penyebab yang utama adalah cleaning manual dan untuk menentukan root cause atau akar masalah digunakan metode analisa 5 Whys ditunjukan Tabel sebagai berikut :

Table 21 Analisa 5 Whys

\begin{tabular}{|l|l|l|l|l|l|l|}
\hline \multicolumn{7}{|c|}{ Cleaning Manual } \\
\hline Why 1 & Why 2 & \multicolumn{1}{|c|}{ Why 3 } & Why 4 & Why 5 & $\begin{array}{l}\text { Root } \\
\text { Cause }\end{array}$ & Action \\
\hline $\begin{array}{l}\text { Operato } \\
\text { r masuk } \\
\text { ke } \\
\text { reaktor }\end{array}$ & $\begin{array}{l}\text { Kerak } \\
\text { di } \\
\text { reakto } \\
\text { r tidak } \\
\text { bisa } \\
\text { bersih }\end{array}$ & $\begin{array}{l}\text { Bagian } \\
\text { atas dan } \\
\text { blade } \\
\text { tidak } \\
\text { terjangka } \\
\text { u }\end{array}$ & $\begin{array}{l}\text { Hanya dibilas } \\
\text { dengan air } \\
\text { menggunaka } \\
\text { n selang }\end{array}$ & $\begin{array}{l}\text { Belu } \\
\text { m ada } \\
\text { alat } \\
\text { yang } \\
\text { efekti } \\
\text { fangana }\end{array}$ & $\begin{array}{l}\text { Alat } \\
\text { cleanin } \\
\text { g tidak } \\
\text { optimal }\end{array}$ & $\begin{array}{l}\text { Menggunakater jet } \\
\text { cleaner } \\
\text { tekanan } \\
\text { tinggi }\end{array}$ \\
\hline
\end{tabular}

(Sumber : Olah Data)

Untuk mencapai sasaran perbaikan yang sesuai dengan akar masalah pada analisa 5 Whys, perusahaan menetapkan sasaran mutu atau KPI (Key Perfomance Indicator) pada bagian produksi yaitu non conforming procces dengan target maksimal 55 jam dengan mempersingkat 
waktu cleaning reaktor menggunakan water jet cleaner dengan tekanan 300 Bar. Pengukuran produktivitas setelah perbaikan dilakukan pada bulan Januari 2019. Ini dikarenakan alat water jet cleaner baru terpasang dan digunakan pada bulan Januari 2019.

Table 22 Nilai Produktivitas Setelah Perbaikan

\begin{tabular}{|c|c|c|c|c|c|}
\hline $\begin{array}{l}\text { Rasio } \\
1\end{array}$ & $\begin{array}{l}\text { Rasio } \\
2\end{array}$ & Rasio 3 & Rasio 4 & Productiv & Criteria \\
\hline 172,09 & 25,93 & 27166,36 & 78,42 & \multicolumn{2}{|c|}{ Performance } \\
\hline 172,88 & 30,85 & 28504,19 & 78,73 & 10 & \multirow{11}{*}{ Score } \\
\hline 168,27 & 29,76 & 27908,18 & 77,63 & 9 & \\
\hline 163,65 & 28,68 & 27312,18 & 76,52 & 8 & \\
\hline 159,04 & 27,59 & 26716,17 & 75,42 & 7 & \\
\hline 154,42 & 26,51 & 26120,16 & 74,72 & 6 & \\
\hline 149,81 & 25,42 & 25524,15 & 73,22 & 5 & \\
\hline 145,19 & 24,34 & 24928,14 & 72,12 & 4 & \\
\hline 140,58 & 23,26 & 24332,14 & 71,01 & 3 & \\
\hline 130,95 & 21,72 & 22477,98 & 67,34 & 2 & \\
\hline 121,32 & 20,18 & 20623,83 & 63,66 & 1 & \\
\hline 111,69 & 18,64 & 18769,68 & 59,99 & 0 & \\
\hline 9 & 5 & 7 & 9 & Skor & \\
\hline 22 & 27 & 27 & 24 & Bobot & \\
\hline 198 & 135 & 189 & 216 & Nilai & \\
\hline \multirow{2}{*}{\multicolumn{3}{|c|}{ Performance Indicator }} & Current & Previous & Index \\
\hline & & & 738 & 300 & $146 \%$ \\
\hline
\end{tabular}

(Sumber : Olah Data)

Table 23 Nilai Indeks Perubahan Produksitas terhadap Produktivitas Sebelumnya

\begin{tabular}{|l|l|l|l|}
\hline Bulan & Nilai & Indeks & Indeks \\
& Produktivitas & Perubahan & Perubahan \\
& Total & $\begin{array}{l}\text { Terhadap } \\
\text { Kinerja } \\
\text { Produktivitas } \\
\text { Standar (\%) }\end{array}$ & $\begin{array}{l}\text { Produktivitas } \\
\text { Sebelumnya (\%) }\end{array}$ \\
& & 146,0 & 3254,5 \\
\hline Januari & 738 & & \\
\hline
\end{tabular}

(Sumber : Olah Data)

Table 24 Pencapaian Skor dari Masing - Masing Rasio di Bulan Januari 2019

\begin{tabular}{|l|l|l|l|l|}
\hline Bulan & \multicolumn{4}{|c|}{ Skor Aktual } \\
\hline Januari & Rasio & Rasio & Rasio & Rasio \\
& 1 & 2 & 3 & 4 \\
\hline
\end{tabular}

(Sumber : Olah Data) 


\section{Kesimpulan}

Berdasarkan uraian-uraian yang telah dikemukakan sebelumnya, maka dapat ditarik kesimpulan, yaitu Nilai produktivitas di bagian produksi sebelum dilakukan pengukuran dengan metode Objective Matrix pada bulan Juli adalah 111,69 dan hanya pada Rasio 1 saja. Setelah dilakukan pengukuran dengan metode Objective Matrix selama 6 bulan periode Juli sampai Desember 2017 diperoleh nilai produktivitas terendah terjadi pada bulan Desember 2017 yaitu 22. Nilai produktivitas mengalami peningkatan setelah ada perbaikan dengan mempersingkat waktu cleaning reaktor dengan menggunakan water jet cleaner bertekanan 300 bar yaitu pada Januari 2019 menjadi 738 atau 560,76\% dibandingkan periode sebelumnya dan mengalami peningkatan $146 \%$ dibandingkan nilai produktivitas standar. Faktor yang menyebabkan nilai produktivitas Rasio 4 paling rendah adalah cleaning reaktor yang sangat lama yaitu selama 24 jam. Cleaning dilakukan secara manual melalui tahapan pembilasan awal dengan air, sirkulasi, blowing dan operator harus masuk setelah dilakukan gas tes serta dinyatakan aman. Cleaning dilakukan secara manual karena belum ada alat yang efektif untuk membersihkan kerak di reaktor.

\section{Daftar Pustaka}

[1] F. A. Pratama and H. Henny, "Analisis Produktivitas Objective Matrix (Omax) Ditinjau Dari Keselamatan Dan Kesehatan Kerja Dilantai Produksi Di Cv. Grand Manufacturing Indonesia," Ina. J. Ind. Qual. Eng., vol. 6, no. 2, pp. 1-8, 2018, doi: 10.34010/iqe.v6i2.987.

[2] G. Jauhari, M. Fitri, and A. S. D. Nova, "PENERAPAN METODE OBJECTIVE MATRIX (OMAX) UNTUK MENGANALISIS PRODUKTIVITAS DI PT. NUSANTARA BETA FARMA PADANG," J. Chem. Inf. Model., vol. 53, no. 9, pp. 1689-1699, 2019, doi: 10.1017/CBO9781107415324.004.

[3] M. P. Nurwantara, "Productivity Analysis Of Coffee Production Process With Objective Matrix (Omax) Method (The Case Study at PT. Perkebunan Kandangan, Pulosari Panggungsari, Madiun)," SEAS (Sustainable Environ. Agric. Sci., vol. 2, no. 1, p. 18, 2018, doi: 10.22225/seas.2.1.538.18-26.

[4] N. H. Hamidah, P. Deoranto, and R. Astuti, "ANALISIS PRODUKTIVITAS MENGGUNAKAN METODE OBJECTIVE MATRIX (OMAX): STUDI KASUS PADA BAGIAN PRODUKSI SARI ROTI PT NIPPON INDOSARI CORPINDO, TBK PASURUAN Productivity Analysis Using Objective Matrix (OMAX) Method: Case Study On The Production Departement Of," J. Teknol. Pertan. Anal. Produkt., vol. 14, no. 3, pp. 215-222, 2013.

[5] L. Susanti, H. raimona Zardy, and B. Yuliandrea, "Pengantar Ergonomi Industri," Andalas Univ. Press, no. May, 2015.

[6] V. Gaspersz, Continuous Cost Reduction Through Lean-Sigma Approach - Strategi 
Dramatik Reduksi Biaya dan Pemborosan Menggunakan Pendekatan Lean-Sigma. Jakarta: PT Gramedia Pustaka Utama, 2006.

[7] F. Fihtri, “Analisa Produktifitas Menggunakan Metode Objective Matrix (OMAX)," J. Optimasi Sist. Ind., vol. 13, No. 1, pp. 548-555, 2014.

[8] T. Afifi and Satriawan, "Analisis Produktivitas Produksi Di Perusahaan Kecap Manalagi Denpasar," J. REKAYASA DAN Manag. AGROINDUSTRI, vol. 03, No. 3, pp. 133-142, 2015 .

[9] S. Phiong, "Pengukuran Kinerja Sumber Daya Manusia Dengan Pendekatan Human Resources Scorecard Dan Alat Ukur OMAX (OBJECTIVE MATRIX) Pada Bagian Produksi PT. Fajarindo Faliman Zipper,” J. Tek. Ind., vol. 08, No. 1, pp. 71-87, 2018.

[10] S. Pakpahan and Ehsy, "Peningkatan Produktivitas Pada PT. Hamson Indonesia," J. Tek. dan Ilmu Komput., vol. Vol. 06, N, pp. 411-434, 2017.

[11] K. Rahmatullah and Wahyuni, "Analisa Produktivitas Pada Divisi Produksi PT. NXZ Menggunakan Metode Objective Matrix,” J. Tek. Ind., vol. Vol. 5, No, pp. 99-104, 2017.

[12] M. Kurniawan and Kholik, "Perancangan Integrated Enviromental Perfomance Measurement System Di Rumah Sakit,” J. Tek. Ind., vol. 18, No. 1, pp. 9-18, 2017.

[13] Suparto, "APPLIED PRODUCTIVITY MEASUREMENT WITH OBJECTIVE MATRIX (OMAX) METHOD (Case Study: Service Department in PT. Astra International Tbk Auto 2000 - Kenjeran Branch)," J. Appl. Ind. Eng. PGRI Adi Buana, vol. 2, no. 2, pp. 26-30, 2019.

[14] H. C. Wahyuni and S. Setiawan, "Implementasi Metode Objective Matrix (OMAX) Untuk Pengukuran Produktivitas Pada PT.ABC," PROZIMA (Productivity, Optim. Manuf. Syst. Eng., vol. 1, no. 1, p. 17, 2017, doi: 10.21070/prozima.v1i1.702.

[15] A. Mail, T. Alisyahbana, A. Saleh, R. Malik, and I. Ibrahim, "ANALISIS PRODUKTIVITAS DENGAN METODE OBJEKTIVE MATRIX (OMAX) PADA CV. BINTANG JAYA,” J. Ind. Eng. Manag., vol. 3, p. 48, 2018, doi: 10.33536/jiem.v3i2.234.

[16] M. Bahrudin and H. C. Wahyuni, "Pengukuran Produktivitas Kerja Karyawan pada Bagian Produksi dengan Menggunakan Metode Objective Matrix (OMAX) Dan Root Cause Analyze (RCA)," PROZIMA (Productivity, Optim. Manuf. Syst. Eng., vol. 1, no. 2, p. 116, 2018, doi: 10.21070/prozima.v1i2.1299.

[17] A. A. Mahmudi, B. Surarso, and A. Subagio, "Kombinasi Balanced Scorecard dan Objective Matrix Untuk Penilaian Kinerja Perguruan Tinggi,” J. Sist. Inf. Bisnis, vol. 4, no. 1, pp. 1-10, 2014, doi: 10.21456/vol4iss1pp01-10.

[18] R. A. Sari, R. Yuniarti, and F. R. N. Safitri, "Evaluasi Kinerja Perusahaan Berdasarkan Perspektif Organisasi, Proses, dan Staf Berbasis AHP dan OMAX," J. Tek. Ind., vol. 19, no. 1 , pp. 49-57, 2018. 
[19] Okfalisa, S. Anugrah, W. Anggraini, M. Absor, S. S. M. Fauzi, and Saktioto, "Integrated analytical hierarchy process and objective matrix in balanced scorecard dashboard model for performance measurement," Telkomnika (Telecommunication Comput. Electron. Control., vol. 16, no. 6, pp. 2703-2711, 2018, doi: 10.12928/TELKOMNIKA.v16i6.9648.

[20] I. R. B. Yosan, I. M. Kholil, and W. Soraya, "Increasing Productivity With Objective Matrix Method Case Study on Building Maintenance Management Pio Pt . Xxx," 9th Int. Semin. Ind. Eng. Manag., 2018.

[21] C. Mulwa, P. Marenya, D. B. Rahut, and M. Kassie, "Response to climate risks among smallholder farmers in Malawi: A multivariate probit assessment of the role of information, household demographics, and farm characteristics," Clim. Risk Manag., vol. 16, pp. 208-221, 2017, doi: 10.1016/j.crm.2017.01.002.

[22] M. M. Rojas-Downing, A. P. Nejadhashemi, T. Harrigan, and S. A. Woznicki, "Climate change and livestock: Impacts, adaptation, and mitigation," Clim. Risk Manag., vol. 16, pp. 145-163, 2017, doi: 10.1016/j.crm.2017.02.001.

[23] E. A. Faridz, "Pengukuran dan analisis produktivitas produksi dengan metode objective matrix (OMAX) di PG. Krebet baru malang," Agrointek, vol. 5, no. 2, pp. 80-87, 2011.

[24] M. A. Wibowo and M. N. Sholeh, "The analysis of supply chain performance measurement at construction project," Procedia Eng., vol. 125, pp. 25-31, 2015, doi: 10.1016/j.proeng.2015.11.005.

[25] F. Tania and M. Ulkhaq, "Pengukuran dan Analisis Produktivitas di PT. Tiga Manunggal Synthetic Industries dengan Menggunakan Metode Objective Matrix ( OMAX )," Ind. Eng. Online J., vol. 5, no. 4, pp. 1-9, 2016.

[26] A. N. Cahyawati, "Penerapan Internal Eksternal Matrix Dan Performance Prism Dalam Upaya Pengukuran Kinerja Rumah Sakit X Malang," J. Ind. Eng. Manag., vol. 2, no. 1, p. 1, 2017, doi: 10.33536/jiem.v2i1.100.

[27] A. Mail, T. Alisyahbana, A. Saleh, R. Malik, and I. Ibrahim, "Analisis Produktivitas Dengan Metode Objektive Matrix (Omax) Pada Cv. Bintang Jaya,” J. Ind. Eng. Manag., vol. 3, no. 2, p. 48, 2018, doi: 10.33536/jiem.v3i2.234.

[28] M. B. Anthony, P. Studi, T. Industri, F. Teknik, U. S. Raya, and P. Tangki, "Pengukuruan Produktivitas Dengan Menggunakan Metode Objective Matrix di PT . ABC," vol. 3, no. 1, pp. 9-19, 2019.

[29] I. Hamdala, W. Azlia, and S. Elman Swara, "Evaluasi Kinerja Rantai Pasok Sari Apel Untuk Meningkatkan Kinerja Perusahaan," J. Ind. Eng. Manag., vol. 2, no. 2, p. 48, 2017, doi: 10.33536/jiem.v2i2.152.

[30] Nasir, "FISHBONE STRATEGY IN TEACHING ENGLISH IN INDONESIA: A TOOL," J. Chem. Inf. Model., vol. 53, no. 9, pp. 1689-1699, 2019, doi: 


\subsection{7/CBO9781107415324.004.}

[31] R. O. Putri and B. M. Wibawa, "Identifikasi Permasalahan Komplain pada E-Commerce Menggunakan Metode Fishbone," J. Sains dan Seni ITS, vol. 6, no. 1, 2017, doi: 10.12962/j23373520.v6i1.21485.

[32] R. Hutagaol, "Analysis of the Implementation of Nursing Professional Values in Referral Hospitals Jakarta: Fishbone Analysis,” Int. J. Nurs. Heal. Serv., vol. 2, no. 1, pp. 108 116, 2019, doi: 10.35654/ijnhs.v2i1.73. 